\title{
Character Environment Care as a Flood Disaster Management Effort
}

\author{
Nina Permatasari 1, Eklys Cheseda Makaria 2, Rochgiyanti 3, Muhammad \\ Andri Setiawan 4
}

DOI: $10.35445 /$ alishlah.v13i2.923

\begin{tabular}{l}
\hline Article Info \\
\hline Keywords: \\
Character Education; \\
Care for the Environment; \\
Flood Disasters
\end{tabular}

Flood Disasters

Kata kunci:

Pendidikan Karakter;

Peduli Lingkungan;

Bencana Banjir

\begin{abstract}
Character education awakens the realm of values and norms of students. Environmental care is one of the 18 character values in the Indonesian Ministry of Education and National (2010) character education design. This article aims to examine the character of caring for the environment to mitigate flood disasters. Qualitative approach with descriptive method is used to describe research problems. Miles and Huberman's interactive model reduced interview data, presented descriptive narratives, and document research results. Triangulation techniques and research extension resulted in data saturation. The results of the study describe that related to the environmental care behavior of the community in Pengaron Village, it is described as follows; 1) The attitude of the community towards flood prevention is to do cooperation every week by coordinating through village officials, 2) Knowledge about flooding is passed down from generation to generation to children. This information includes the fact that floods always occur every year, so people must always be alert; 3 ) Environmental care behavior includes the obligation to have swimming skills, construct houses on stilts and or two floors, and plant trees that have characteristics sensitive to weather changes. Society inherits the character of caring for the environment as the primary value in everyday life. The character of caring for the environment contributes to educating the importance of preserving and coexisting with the environment.
\end{abstract}

\begin{abstract}
Abstrak
Pendidikan karakter menggugah ranah nilai dan norma peserta didik. Satu dari 18 nilai karakter pada desain pendidikan karakter Kementerian Pendidikan dan Nasional Indonesia (2010) adalah peduli lingkungan. Artikel ini bertujuan menelaah karakter peduli lingkungan sebagai upaya mitigasi bencana banjir. Pendekatan kualitatif dengan metode deskriptif digunakan untuk menguraikan permasalahan penelitian. Model interaktif Miles dan Huberman digunakan untuk mengurangi data wawancara, menyajikan narasi deskriptif dan hasil dokumentasi penelitian. Teknik triangulasi dan perpanjangan penelitian menghasilkan kejenuhan data. Hasil penelitian mendeskripsikan bahwa terkait dengan perilaku peduli lingkungan masyarakat di Desa Pengaron dijabarkan sebagai berikut; 1) Sikap masyarakat terhadap penanggulangan banjir adalah melakukan gotong-royong setiap
\end{abstract}

\footnotetext{
${ }^{1}$ Counseling Education, Lambung Mangkurat University, Banjarmasin City, Indonesia Email: nina.bk@ulm.ac.id 2 Counseling Education, Lambung Mangkurat University, Banjarmasin City, Indonesia Email: eklys.makaria@ulm.ac.id

3 History Education, Lambung Mangkurat University, Banjarmasin City, Indonesia

Email: yantiunlam87@ulm.ac.id

4 Counseling Education, Lambung Mangkurat University, Banjarmasin City, Indonesia

Email: andri.bk@ulm.ac.id
} 
minggu dengan berkoordinasi melalui petugas desa, 2) Pengetahuan tentang banjir diwariskan secara turun temurun kepada anak. Informasi ini meliputi fakta bahwa banjir selalu terjadi setiap tahun, sehingga masyarakat harus selalu siaga, 3) Perilaku peduli lingkungan melingkupi kewajiban untuk memiliki keterampilan renang, mengkonstruksi rumah panggung dan atau berlantai dua, serta menanam pohon yang memiliki karakteristik peka terhadap perubahan cuaca. Masyarakat mewariskan karakter peduli lingkungan sebagai nilai utama dalam kehidupan sehari-hari. Karakter peduli lingkungan berkontribusi terhadap sarana edukasi pentingnya menjaga dan hidup berdampingan dengan lingkungan.

\section{INTRODUCTION}

The Indonesian Ministry of National Education instills character building through education since 2010 contained in the National Action Plan for Character Education (Marjohan \& Afniyanti, 2018; Wibowo, 2020). Character education is determined by the ministry of education totaling 18 values or characters originating from religion, Pancasila, culture, and national education goals. These values or characters are religion, honest, tolerance, discipline, hard work, creativity, independence, democratic, curiosity, national spirit, love for the homeland, respect for achievement, communicative friendship, love of peace, love to read, care for the environment, social care, and responsibilities (Fajarini, 2014).

In particular, the link between character education and environmental care is intended as attitudes and actions that always try to prevent environmental damage (Syaharuddin et al., 2020). In addition, it is hoped that environmental care will develop efforts to repair the natural damage that has occurred. The character of caring for the environment is an attitude possessed by someone who seeks to improve and manage the surrounding environment properly so that the environment can be enjoyed continuously without damaging its condition, as well as maintaining and preserving it so that there are sustainable benefits (Mutiani et al., 2020).

Research related to the character of caring for the environment as the focus of the study for disaster management has been carried out. One of them suggested that environmental concerns must be aligned with political policies. In particular, this case is highlighted in mining in the U.S. Coal Industry (Weber, 2020). However, in contrast to this research, this study focuses on environmental problems due to annual disasters. The relationship between character education and environmental care is also expected to respond to environmental problems. For example, one environmental problem that has turned into a disaster is flooding.

Referring to data from the National Disaster Management Agency (BNPB), since the beginning of 2021, 386 disasters have occurred in Indonesia, dominated by floods with 232 activities (BBC, 2021). Based on BNPB data for South Kalimantan Province, The South Kalimantan Provincial Government has established a Flood Disaster Emergency Response Status on January 14, 2021. It was recorded that 24,379 houses were flooded and 39,549 residents evacuated with details, among others, Tapin Regency as many as 582 houses were affected and 382 people evacuated, Banjar Regency 6,670 houses were affected, and 11,269 People were displaced, Banjar Baru City was 2,156 affected, and 3,690 people were displaced. Tanah Laut City was 8,506 houses affected, with 13,062 people displaced (BNPB, 2021).

The overall description of the data above explains that the flood disaster in South Kalimantan, with the most affected victims, was Banjar Regency. Of course, this matter leaves a prolonged polemic. Various efforts have been made, from normalizing river flows and destroying toilets on riverbanks (Annisa et al., 2022; Prihartini et al., 2021). However, floods still occur. Therefore, an educational approach with internalizing the character of caring for the environment deserves to be developed. The purpose of the goal is simply an awareness of thinking, acting, and behaving towards the environment. This article aims to examine the character of caring for the environment as an effort 
mitigation floods. Thus, through the character of caring for the environment, it is hoped that the community can massively cope with flood disasters as a form of behavior preventive.

\section{METHODS}

The approach chosen is qualitative with a descriptive method. The qualitative approach is understood as a structured procedure in which the data generated is descriptive data. It is a series of descriptive data in spoken and written words in subjects and observed behavior (Creswell, 2010; Hennink et al., 2020). The characteristics inherent in the qualitative approach are the natural setting (Mohammad, 2008; Park \& Park, 2016). Natural setting related to the annual flood disaster that occurred in Banjar Regency, Pengaron Village. In the technique of collecting data, it is carried out in stages; 1) Observation of Pengaron Village, precisely in RT 02, 03, 04, and 05; 2) Interviews with indepth interview techniques were conducted with 22 sources as research subjects; 3) Documentation related to floods and news published by the media were collected by researchers (Neuman, 2015; Strauss \& Corbin, 1990). The following table lists the names of the sources;

Table 1. List of Resource Persons

\begin{tabular}{cccc}
\hline No & Name & Age & Profession \\
\hline 1 & SJB & 38 years old & Village Supervisory Board \\
2 & MR & 42 years old & Health Center Staff \\
3 & SBR & 36 years old & Gardening \\
4 & SP & 45 years old & Gardening \\
5 & OV & 5 o years & Motorcycle taxis driver \\
6 & MM & 48 years old & self-employed \\
7 & GTC & 53 years old & Farmer \\
9 & NL & 28 years & self-employed \\
10 & MD & 44 years old & village secretary \\
11 & MN & 34 Years & Village Officer \\
12 & AWY & 49 years old & Pengaron Police \\
13 & AR & 53 years old & Farmer (Head of RT 2) \\
14 & TFQ & 44 years old & Village Head \\
15 & HKS & 54 years old & Farmer (Head of RT 4) \\
16 & SJ & 36 years old & Head of RT 1 \\
17 & RK & 23 years & Village officials \\
18 & MMD & 23 years & entrepreneur (head of RT 3) \\
19 & Tarmiji Tohir & 35 years old & Trader \\
20 & SG & 40 Years & Trader \\
21 & RM & 45 years old & Trader \\
22 & SG & 53 years old & Trader \\
\hline
\end{tabular}

Source; Rearchers (data processed, 2021)

The analysis technique used an interactive model from Miles and Huberman. Interview data dominate data reduction. This matters because interview results were found that were out of the research context. Display data in narrative text and several pictures related to the flood disaster in Pengaron Village (Sugiyono, 2016; Yusuf, 2017). Increased validity of research data study conducted member checks, extended observations in October 2020, and triangulated data (Elliott \& Timulak, 2005; Satori \& Komariah, 2014). The data collected was then compared to focus on research. In general, the data description explains that the character of caring for the environment contributes to flooding prevention. Through an attitude of caring for the environment, the community and the village apparatus of Pengaron work together to clean the river and the surrounding environment once a week (Farquhar et al., 2020). 


\section{FINDINGS AND DISCUSSION}

The term character comes from the Latin character, which means character, character, psychological nature, character, personality, and morals. The term character was also adopted from the Latin character, kharessian, and xharaz, which means tools for marking, engraved, and pointed stake, later understood as stamps or stamps (Fitria et al., 2019)-in English, translated into character. The word character is also often interpreted as a character. Character is a set of traits that are admired as signs of virtue and one's moral maturity. The character, which means carving to form a pattern, requires a long process through education (Elias, 2013). Character education is an active effort to form habits (habits) so that the nature of children is carved from an early age, somewhat able to make good and wise decisions and practice them in everyday life (Elias, 2009; Saidek et al., 2016). Character education believes in absolute morals. Namely, absolute morals need to be taught to the younger generation to understand what is good and right.

Environmental care character education is developed through efforts to instill sensitivity and concern for the environment. Efforts to protect the environment are described in Law Number 32 of 2009 concerning Environmental Protection and Management Article 1 paragraph (2). The research and development agency, the Curriculum Center of the Ministry of National Education, stated that character education materials cover many aspects. The aspects of character education include religion, honesty, tolerance, discipline, hard work, creativity, independence, democratic, curiosity, national spirit, love for the homeland, appreciating achievements, friendly and communicative, love peace, love to read, care for the environment, social care, and responsibility. Caring for the environment is one of the characters that must be developed in schools. Caring for the environment is an attitude and action that always tries to prevent damage to the surrounding natural environment and develops efforts to repair the natural damage that has already occurred (Mutiani et al., 2020; Sari, 2014). Caring for the environment is a character that students must own. The character of caring for the environment can reflect the care and sensitivity of students to their environment.

Caring for the environment is an attitude and action that always tries to prevent damage to the surrounding natural environment and develops efforts to repair the natural damage (Mutiani, 2017). The environment is where we are. Therefore, the environment must be maintained as well as possible. Do not let the environment be left damaged without any maintenance and updates. Caring for the environment is the solution to the crisis of environmental concern: many floods, landslides, and air pollution resulting from a lack of concern for the environment. Through character education, it is expected to be able to generate and realize environmental awareness. The trick is to educate all elements of society about the importance of protecting the environment (Lai, 2018; Walter, 2009).

Education and caring for the environment refer to three main aspects. First, knowledge (cognitive) includes an understanding of the natural causes of environmental problems. Second, both attitudes (affective) include awareness to solve environmental problems-alertness to a bigger problem, such as a disaster. Third, the three actions (psychomotor) include participation in preventive behavior for disaster management. Of course, this requires synergy between elements. Not only pivot on the education unit. However, it cannot be denied that education and character building are carried out in macro and micro contexts (Mancha \& Yoder, 2015; Weber, 2020). In the macro context, the implementation of character education includes planning, organizing, implementing, and quality control, which involves all significant units within the national education stakeholder environment. Whereas in the micro context, it implements character education at the school level (Syaharuddin et al., 2020; Weber, 2020).

It is related to the urgency of environmental care character education as an effort to overcome floods. Real problems can be taken from various regions; South Kalimantan is no exception. One area that is regularly hit by floods is Pengaron Village. Based on the results of interviews with the Head of the Village Environment, TFQ (44 years), that; 
"Flood disaster in Pengaron occurs not only once a year. However, it can reach four times a year. It is strongly influenced by the volume of water from upstream flowing through the Pinang River. The situation will get worse if added with heavy rainfall. Based on this, we as residents who have lived in Pengaron Village must be alert to these problems for many years".

Based on the interview results above, it is known that flooding is an unavoidable condition in Pengaron Village. The community is hereditary, providing character education to care for the environment as an attitude in everyday life. Pengaron Village intentionally plants tamarind trees (a type of manga), such as; Kasturi, mango, kuweni, servant, and others. The choice of trees is not without reason, but if the tree flowers are white, it is a sign of the start of the rainy season. Based on the results of an interview with SP (50 years), that:

"Tamarind tree species that are red, such as; kuweni, servant, ampalam, and others.

If it has released its flowers with a red color and comes from plants that grew because of seeds, summer has come".

People in Pengaron Village know environmental care in a more basic context: preparing shelters safe from flooding. The primary thing that can be considered is constructing houses with higher house sticks, especially housing that juts directly into the Batang Banyu River. The stick used is a type of ironwood (sometimes called ironwood) that is durable even in puddles of water. If possible, the walls of the house are made of ironwood. So that the house is not easily weathered. Even if the flood disaster is too severe, it is believed that ironwood can withstand the impact of the wood that dissolves during the wet. Here's a picture of when the flood occurred in Pengaron Village.
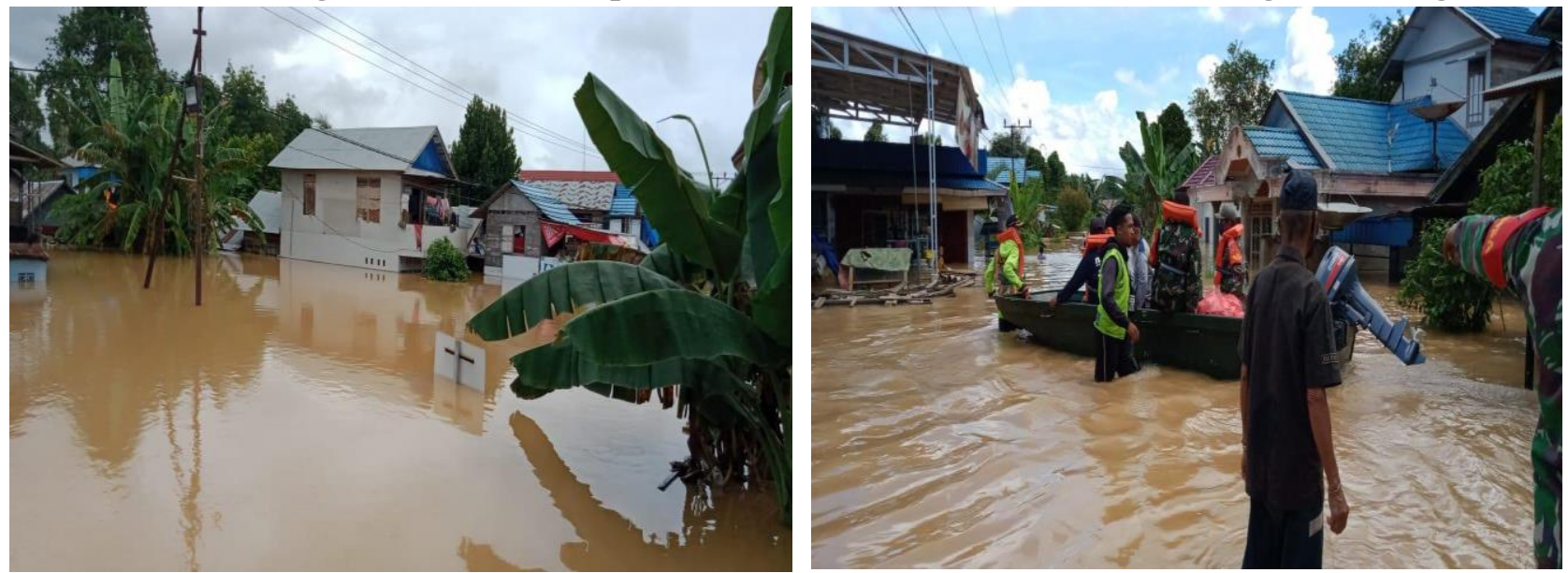

Figure 1. Pengaron Village Flood, January 14, 2021

The picture above describes how the flooding in Pengaron Village was relatively high and dangerous for children. Therefore, another form of anticipation, specifically for children on the river banks, is the obligation to have swimming skills. Since the age of two, they have started to learn to swim with friends. Their parents do not teach them. The better at swimming, the more often play in the river. Bathing in the river is the favorite pastime of local children. So that through the games they play every day, they can hone their swimming skills which are a demand in the event of a flood. Thus, parents tend to be calmer because their children can take care of themselves with swimming skills.

Character education is an umbrella term that describes various aspects of teaching and learning for personal development. Some under the umbrella include "moral reasoning/cognitive development; social and emotional learning, education Policy morals, life skills education, health education, violence prevention, conflict resolution and moral, ethical philosophy (Mutiani, 2017). The establishment of the character of caring for the environment for the community can certainly be used as a concrete form of disaster management. Character education, identical to the cultivation of morality and values in everyday life, cannot be processed quickly. The synergy between elements helps construct values in good behavior. The following is a schematic illustration of the urgency of the character caring for the environment in flood prevention: 


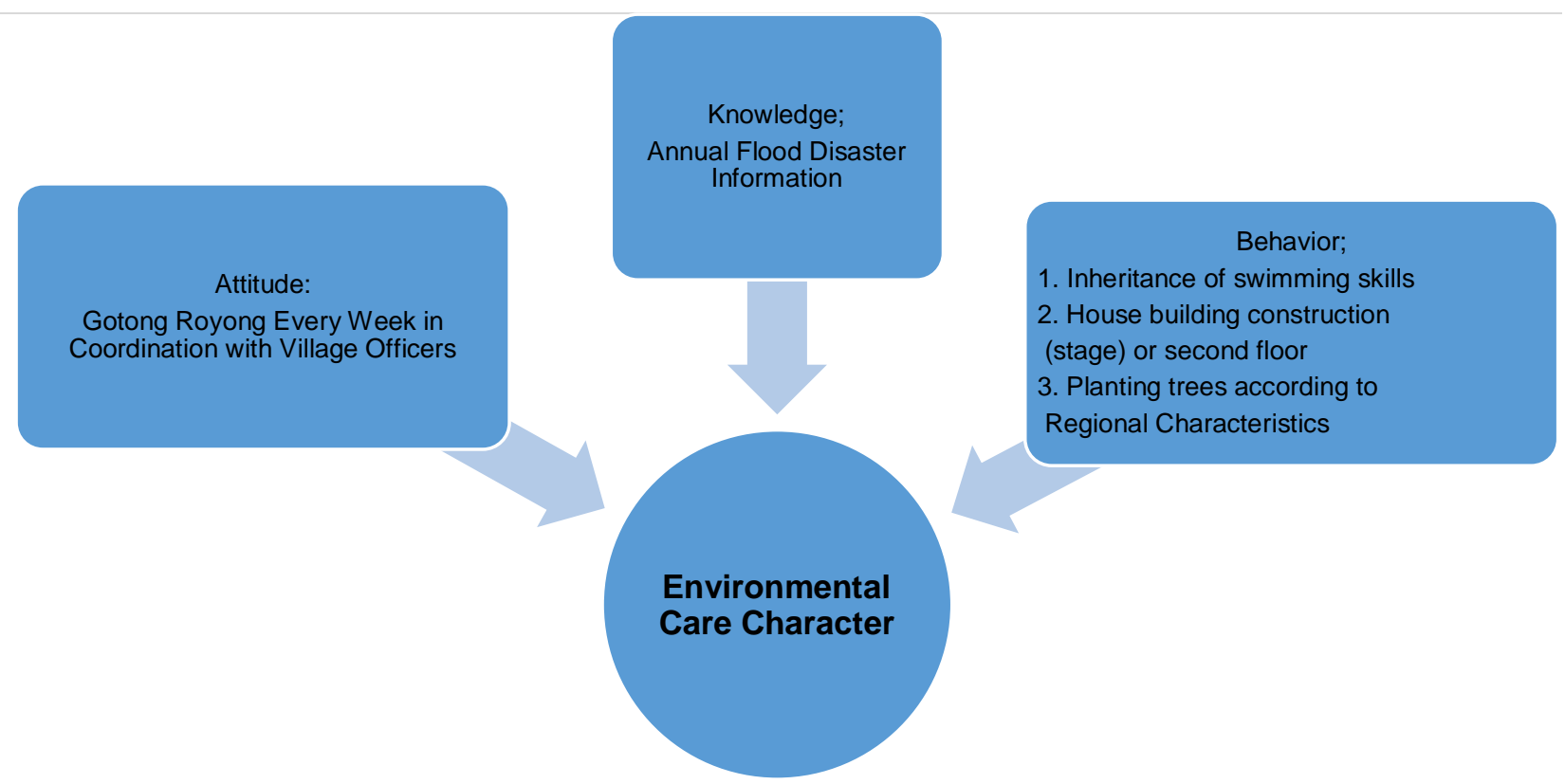

Figure 2. Environmental Care Character in Flood Management

The character of caring for the environment is not entirely an innate talent or instinct but is also the result of an educational process in a broad sense. Character is not merely an individual's innate talent, but is the result of human formation and the environment in which he lives, lives, and is raised (Marjohan \& Afniyanti, 2018). Moreover, how to shape that character, academically, of course, the answer is only one, namely "education" (Wibowo, 2020). Education makes it possible to shape character as a human being as expected. Environmental education is an unavoidable necessity if we want to create a civil society as we aspire to. Environmental education aims to shape human character concerning the environment for the benefit (Larijani, 2010; Mutiani et al., 2021).

In the simple scheme described above, the character who cares for the environment has an attachment between; attitudes, knowledge, and behavior. The theoretical character of environmental care, which is a manifestation of human attitudes towards the environment, can suppress antipathetic behavior. As in Pengaron Village, the environment has various characteristics, one of which is prone to disasters. Therefore, the character of caring for the environment can become an identity in preserving nature. This matter is based on the conception that humans and the environment are bound to each other (Mutiani et al., 2020; Walter, 2009). Therefore, we must see that character education is not only presented in schools. Public around. Education in practical terms can use it as teaching materials and learning resources. Thus, the phenomena that occur in society are not only empty events without meaning. However, it can be used as an object of study of exemplary behavior to protect the environment.

\section{CONCLUSION}

The character of caring for the environment is not entirely an innate talent or instinct but is also the result of an educational process in a broad sense. Environmental care character refers to three main aspects. First, knowledge (cognitive) includes an understanding of the real causes of environmental problems. Second, both attitudes (affective) include awareness to solve environmental problems-alertness to a bigger problem, such as a disaster. Finally, the three actions (psychomotor) include participation in preventive behavior for disaster management. Regarding the environmental care behavior of the community in Pengaron Village, it is described as follows; 1) The community's attitude towards flood prevention is to cooperate every week by coordinating through village officials, 2) Knowledge about flooding is passed down from generation to generation to children. This information includes the fact that floods always occur every year, so people must 
always be alert; 3) Environmental care behavior includes the obligation to have swimming skills, construct houses on stilts and or two floors, and plant trees that have characteristics sensitive to weather changes, such as trees, mango, kuweni, and ampalam. The theoretical character of environmental care, which is a manifestation of human attitudes towards the environment, can suppress antipathetic behavior. As in Pengaron Village, the environment has various characteristics, one of which is prone to disasters. The environment as in Pengaron Village has various characteristics, one of which is prone to disasters. The character of caring for the environment can become an identity in preserving nature. This matter is based on the concept that humans and the environment are bound to each other.

\section{REFERENCES}

Annisa, M., Asrani, A., Serlinda, S., Kasih, S., \& Maulana, S. (2022). Analysis of Students ' Knowledge About Natural Disaster Mitigation in Wetland Areas. Journal of Innovation in Educational and Cultural Research, 3(1), 12-19. https://doi.org/10.46843/jiecr.v3i1.45

BBC. (2021, February 11). Banjir dan bencana beruntun di tengah cuaca ekstrem, "Menurut pemerintah itu anomali cuaca, kami menyebutnya krisis iklim.” BBC News Indonesia. https://www.bbc.com/indonesia/indonesia-56007558

BNPB. (2021, January 17). [Update] - 10 Kabupaten/Kota Terdampak Banjir di Kalimantan Selatan - BNPB. Bnpb.Go.Id. https://bnpb.go.id/berita/-update-10-kabupaten-kotaterdampak-banjir-di-kalimantan-selatan

Creswell, J. W. (2010). Research Design Pendekatan Kualitatif, Kuantitatif, dan Mixed. Pustaka Pelajar.

Elias, M. J. (2009). Social-Emotional and Character Development and Academics as a Aual Focus of Educational Policy. Educational Policy, 23(6), 831-846. https://doi.org/10.1177/0895904808330167

Elias, M. J. (2013). The character of schools, the character of individuals, and the character of society: Creating educational policy to reflect this inextricable interconnection. Korean Journal of Educational Policy, 10(3), 141-149.

Elliott, R., \& Timulak, L. (2005). Descriptive and interpretive approaches to qualitative research. In $A$ handbook of research methods for clinical and health psychology. Oxford University Pers. https://doi.org/10.1093/med:psych/9780198527565.001.0001

Fajarini, U. (2014). Peranan Kearifan Lokal dalam Pendidikan Karakter. SOSIO DIDAKTIKA: Social Science Education Journal, 1(2), 123-130. https://doi.org/10.15408/sd.v1i2.1225

Farquhar, J., Michels, N., \& Robson, J. (2020). Triangulation in industrial qualitative case study research: Widening the scope. Industrial Marketing Management, 7, 1-11. https://doi.org/10.1016/j.indmarman.2020.02.001

Fitria, H., Kristiawan, M., \& Rasyid, A. (2019). The educational character on instruction. Opción, 21, 964-979.

Hennink, M., Hutter, I., \& Bailey, A. (2020). Qualitative research methods. SAGE.

Lai, C.-S. (2018). A Study of Fifth Graders' Environmental Learning Outcomes in Taipei. International Journal of Research in Education and Science, 252-262. https://doi.org/10.21890/ijres.383171

Larijani, M. (2010). Assessment of Environmental Awareness among Higher Primary School Teachers. Journal of Human Ecology, 31(2), 121-124. https://doi.org/10.1080/09709274.2010.11906302

Mancha, R. M., \& Yoder, C. Y. (2015). Cultural antecedents of green behavioral intent: An environmental theory of planned behavior. Journal of Environmental Psychology, 43, 145154. https://doi.org/10.1016/j.jenvp.2015.06.005

Marjohan, M., \& Afniyanti, R. (2018). Penerapan Nilai Pendidikan Karakter Peduli Lingkungan Di Kelas Tinggi Sekolah Dasar. Jurnal Gentala Pendidikan Dasar, 3(1), 111-126. https://doi.org/10.22437/gentala.v3i1.6767

Mohammad. (2008). Metode Penelitian Kuantitatif-Kualitatif. UIN.

Mutiani, M. (2017). IPS dan Pendidikan Lingkungan: Urgensi Pengembangan Sikap Kesadaran Lingkungan Peserta Didik. SOSIO-DIDAKTIKA: Social Science Education Journal, 4(1), 4553. https://doi.org/10.15408/sd.v4i1.5718

Mutiani, Noortyani, R., Tetep, Jumriani, \& Widyanti, T. (2020). Strengthening Islamic 
Environmental Awareness through Exploring Poetry as a Learning Resource in Social Studies. Islam Realitas: Journal of Islamic and Social Studies, 6(2), 150-163.

Mutiani, Rahman, A. M., Permatasari, N., Abbas, E. W., \& Putra, M. A. H. (2021). Kecerdasan Ekologis Perajin Tanggui Di Bantaran Sungai Barito. Jurnal Publikasi Berkala Pendidikan Ilmu Sosial, 1(1), 69-79.

Neuman, W. L. (2015). Metodologi Penelitian Sosial: Pendekatan Kualitatif Dan Kuantitatif. PT Indeks.

Park, J., \& Park, M.-H. (2016). Qualitative versus Quantitative Research Methods: Discovery or Justification? Journal of Marketing Thought, 3(1), 1-8.

Prihartini, P., Aini, M., Sya'diah, N., \& Tazkianida, R. F. (2021). Model Pelayanan Pekerja Sosial Terhadap Korban Bencana Banjir Di Kota Banjar Provinsi Kalimantan Selatan Tahun 2021. Jurnal Manajemen Bencana (JMB), 7(1), 37-44. https://doi.org/10.33172/jmb.v7i1.694

Saidek, A. R., Raisul Islami, \& Abdoludin. (2016). Character Issues: Reality Character Problems and Solutions through Education in Indonesia. Journal of Education and Practice, 7(17), 158-165.

Sari, Y. M. (2014). Pembinaan Toleransi Dan Peduli Sosial Dalam Upaya Memantapkan Watak Kewarganegaraan (Civic Disposition) Siswa. Jurnal Pendidikan Ilmu Sosial, 23(1), 15-26. https://doi.org/10.17509/jpis.v23i1.2059

Satori, D., \& Komariah, A. (2014). Metodologi Penelitian Kualitatif. Alfabeta.

Strauss, \& Corbin. (1990). Basics of Qualitative Research: Grounded Theory Procedures and Techniques. Sage publication.

Sugiyono. (2016). Memahami Penelitian Kualitatif. Alfabeta.

Syaharuddin, S., Hidayanti, H., \& Mutiani, M. (2020). The Role of Waste Banks to Improve Community Environment Awareness. The Innovation of Social Studies Journal, 1(2), 129-138. https://doi.org/10.20527/iis.v1i2.2026

Walter, P. (2009). Local knowledge and adult learning in environmental adult education: Community-based ecotourism in southern Thailand. International Journal of Lifelong Education, 28(4), 513-532. https://doi.org/10.1080/02601370903031363

Weber, J. (2020). How Should We Think about Environmental Policy and Jobs? An Analogy with Trade Policy and an Illustration from US Coal Mining. Review of Environmental Economics and Policy, 14(1), 44-66.

Wibowo, E. W. (2020). Analisis Pendidikan Karakter Religius, Peduli Sosial, Dan Peduli Lingkungan Terhadap Kedisiplinan (Studi Kasus Mahasiswa Administrasi Perkantoran Politeknik LP3I Jakarta). Jurnal Lentera Bisnis, 9(2), 31-38. https://doi.org/10.34127/jrlab.v9i2.379

Yusuf, A. M. (2017). Metodologi Penelitian Kuantitatif, Kualitatif \& Penelitan Gabungan. Prenadamedia Group. 